\title{
Insect Effigy Pendants
}

Jesse Todd

MA Consulting

Follow this and additional works at: https://scholarworks.sfasu.edu/ita

Part of the American Material Culture Commons, Archaeological Anthropology Commons, Environmental Studies Commons, Other American Studies Commons, Other Arts and Humanities Commons, Other History of Art, Architecture, and Archaeology Commons, and the United States History Commons

Tell us how this article helped you.

This Article is brought to you for free and open access by the Center for Regional Heritage Research at SFA ScholarWorks. It has been accepted for inclusion in Index of Texas Archaeology: Open Access Gray Literature from the Lone Star State by an authorized editor of SFA ScholarWorks. For more information, please contact cdsscholarworks@sfasu.edu. 
Insect Effigy Pendants

Creative Commons License

(c) $($ ) $(9)$

This work is licensed under a Creative Commons Attribution-NonCommercial 4.0 International License 


\title{
INSECT EFFIGY PENDANTS
}

\author{
Jesse Todd \\ MA Consulting
}

Abstract: This short paper concerns the presence of zoomorphic pendants on Caddoan sites and the history of possible beliefs concerning locusts and cicadas in the southeastern United States. The aspect of pendants used as trade items is mentioned also.

Webb (1959:172) recovered several conch shell pendants from the Belcher site. One necklace from Burial 1 in Pit 23 contained 37 shell pendants (Figure 1). Perino (1969:128) stated that the pendants resembled lizards, but Jackson (1935:22fn) referred to them as locust pendants. From sites such as Poverty Point which were occupied prior to Caddoan times, zoomorphic beads were recovered which Webb (1971) and Morse and Morse (1982) believe resembled either locusts (commonly called grasshoppers) or cicada

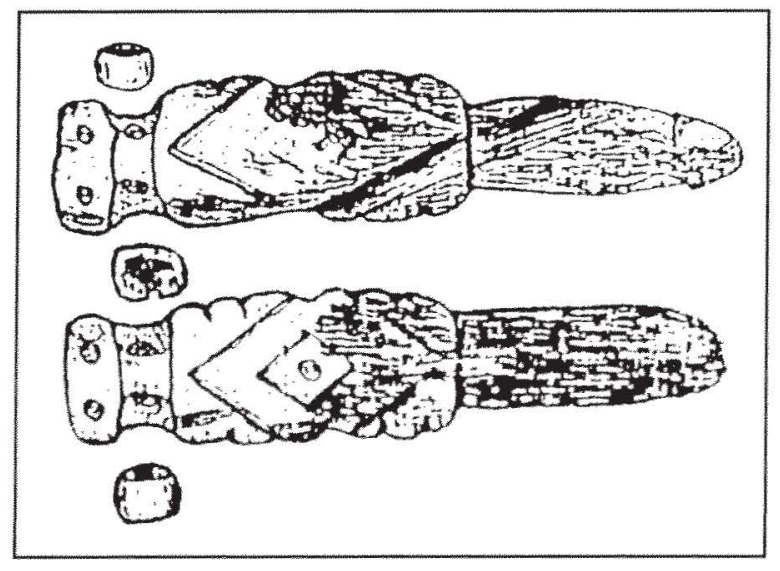

Figure 1. Zoomorphic pendants from the Belcher Mound; from Webb 1959:106. (commonly called locusts) or had attributes of both. A bead recovered from Poverty Point had dominant abdominal ridges similar to those of the locust, whereas another bead had a large thoracic region which resembled the auditory membrane of the locust (Webb 1971:111112).

Webb (1971:113) states that the zoomorphic beads represented the cicada and locust because they make loud music and locust has powerful hind legs. In addition, their eruption from the earth gives the insects a magical appearance. Since both the cicada and locust bury their eggs in the earth (Comstock 1976), both insects should have the same magical attributes of birth (or rebirth) during the summer. Morse and Morse (1982), in their discussion of the cicada, point out that it burrows into the earth and emerges to fly while making an incredible noise. The locust should as well.

Hunter et al. (1975:222) discuss the role of the cicada among the Coushatta. The cicada is associated with agriculture. 


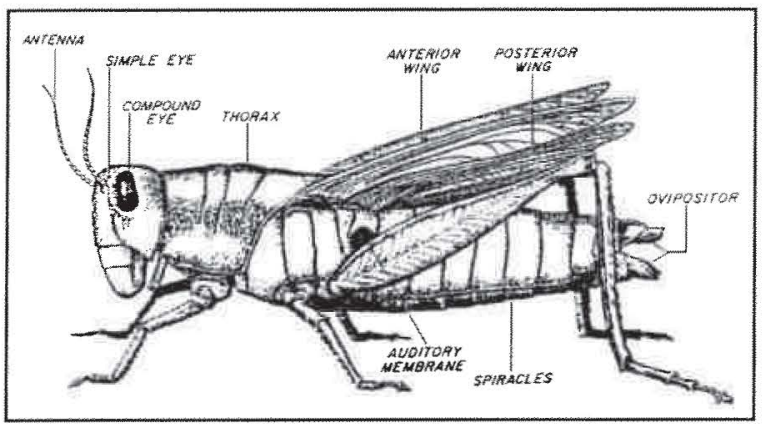

Figure 2. External anatomy of a locust; from Webb (1971:111).

According to Hunter et al. (1975:222), Mr. Bel Abbey stated that his grandmother knew when roasting ears (green corn) were ready by the sound of the cicada. The cicada's song begins in late June or early July, the time when the corn ripens (Hunter et al. 1975:222). It appears that the beliefs concerning the cicada, and probably the locust, existed from Archaic to modern times in the southeastern United States (Hunter et al. 1975; Morse and Morse 1982:122).

As far as which insect the beads represent, they probably have attributes of both the locust and cicada. The zoomorphic pendants from the Belcher Mound are not carved in as much detail as the beads; therefore, they are more problematic. Figure 2 is a drawing of a locust (grasshopper) and Figure 3 is a drawing of a cicada (locust) for comparison to the pendant illustrated in Figure 1. When one looks at these zoomorphic pendants recovered from Belcher Mound and other Caddoan sites, to me, the distinct impression is of a locust. The abdominal ridges can not be seen from above the insect in either the locust or cicada; however, the narrow bottom portion of the locust is easily noted. This narrow bottom portion is recognizable in the pendants, also. Unfortunately, when one looks at the top of the pendant, the blunt head may represent either the locust or cicada because both insects have blunt heads and eyes on the side of their head. The blunt head may be simply there so that the conch shell beads may fit with the pendant as illustrated in Figure 1.

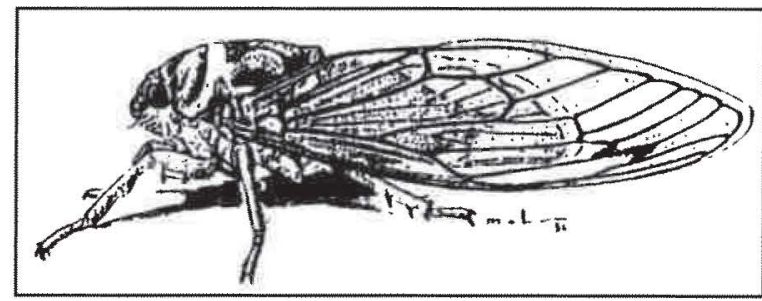

Figure 3. External anatomy of a cicada; from Buror et al (1971:296).

Zoomorphic (insect) pendants have been recovered from at least six Caddoan archeological sites. There is also a locust effigy boatstone carved from quartz crystal from Spiro (Brown 1996:466, Figure 270). The sites are presented in Table 1 and geographically located in Figure 4.

If the cicada and locust are associated with agriculture, they would play an important part in announcing the ripening of the corn. The Coushatta associating the cicada with agriculture would appear to support the reason for the shell effigies at the Belcher Mound and possibly Poverty Point as well. Corn was probably of prime importance during Belcher Phase I (Webb 1959:172). The presence of corn has not been confirmed for Poverty Point, 
although some form of cultigen besides corn may have been present.

If the locust effigies from the Belcher site are similar in nature to the locust beads from Poverty Point and throughout the Central Mississippi Valley, it possibly suggests a belief that existed from the Archaic to the historic Native Americans of the southeastern United States. An alternative explanation for the presence of the pendants in the Caddoan area is that they were used as a symbol from the past that has a new meaning. Unfortunately, there is not a continuous artifactual record of the locust or cicada being used as an effigy from Archaic to Historic Native American times. Hunter et al. (1975:220) state that the absence of the locust effigy may merely mark the decline in the lapidary industry, but in no way signifies



Figure 4. Locations of sites where locust pendants or effigies have been found.

the loss of folk traditions concerning the insect such as the Coushatta have.

Table 1. Locations of Locust Pendants and Effigies from Caddoan Sites.

\begin{tabular}{|l|l|}
\hline \multicolumn{1}{|c|}{ Site } & \multicolumn{1}{|c|}{ Reference } \\
\hline \hline 1. Belcher Mound, Caddo Parish, Louisiana & Webb (1959) \\
\hline 2. L.L. Winterbauer Farm, Wood County, Texas & Jackson (1935) \\
\hline 3. Clement Brothers Farm, Cass County, Texas & Jackson (1935) \\
\hline 4. Sam Kaufman site, Red River County, Texas & $\begin{array}{l}\text { Harris (1953); } \\
\text { Skinner, Harris, and Anderson (1969) }\end{array}$ \\
\hline 5. Joe Russel Place, Lafayette County, Arkansas & Perino (1969) \\
\hline 6. Foster Mound, Hempstead County, Arkansas & Skinner, Harris, and Anderson (1969) \\
\hline $\begin{array}{l}\text { 7. Spiro Mound, Le Flore County, Oklahoma } \\
\text { (effigy boatstone) }\end{array}$ & Brown (1996) \\
\hline \hline
\end{tabular}




\section{Conclusion}

The presence of these shell locust pendants on archeological sites in Arkansas, Louisiana, and Texas suggest trade among the sites in the area. It may be inferred as well that there was a common belief system. The presence of the pendants also suggest some form of agriculture at the sites listed in Table I.

\section{References Cited}

Borror, Donald J., Dwight M. DeLong, and Charles A. Triplehorn

1971 An Introduction to the Study of Insects, fourth edition. Holt, Rinehart, and Winston, New York.

\section{Brown, James A.}

1996 The Spiro Ceremonial Center: The Archeology of Arkansas Valley Caddoan Culture in Eastern Oklahoma. Memoirs of the Museum of Anthropology, Number 29. University of Michigan, Ann Arbor.

Comstock, John Henry

1967 [1920] An Introduction to Entomology, ninth edition. Comstock Publishing Associates, New York.

Harris, R.K.

1953 The Sam Kaufman Site, Red River County, Texas. Bulletin of the Texas Archeological Society 24:43-68.

Hunter, Donald G. [in association with Bel Abbey, Nora Abbey, and Louisa Wilson]

1975 The Cicada in Southeastern Archaeology and in Coushatta Tradition. Louisiana Archaeology 2:219-226.
Jackson, A.T.

1935 Ornaments of East Texas. Bulletin of the Texas Archeological and Paleontological Society 17:1-28.

Morse, Dan F., and Phyllis A. Morse 1982 Archaeology of the Central Mississippi Valley. Academic Press, New York.

Perino, Gregory

1969 Shells and Their Use by the Indians. Central States Archaeological Journal 16(3):128-133.

Skinner, S. Alan, R.K. Harris, and Keith M. Anderson (editors)

1969 Archaeological Investigations of the Sam Kaufman Site, Red River County, Texas. Southern Methodist University, Contributions in Anthropology 15. Dallas.

Webb, Clarence H.

1959 The Belcher Mound. Memoirs of the Society for American Archaeology 16.

1971 Archaic and Poverty Point Zoomorphic Locust Beads. American Antiquity 36(1):105-114. 